\title{
Selected mutli-drug-resistance-organisms in selected Polish long-term-care facilities*
}

\author{
J Wojkowska-Mach, D Romaniszyn, M Pobiega, B Gryglewska, T Grodzicki \\ From International Conference on Prevention \& Infection Control (ICPIC 2011) \\ Geneva, Switzerland. 29 June - 2 July 2011
}

\section{Introduction / objectives}

Nosocomial infections and antimicrobial resistance (AR) are a very well-known public health problems. Unfortunately, up to now there is no surveillance of AR in Polish long term care facilities (LTCF). The aim of this presentation was to analyze prevalence of selected Multi-Drug-Resistance-Organisms (MDRO) among residents of LTCFs in Krakow, Poland.

\section{Methods}

The study was carried out from 10-2009 to 11-2010 in 3 public LTCF on a group of 193 residents. Screening test for MRSA and ESBL(+) Gram-negative rods were done at the beginning of the study. Also urine and wound cultures were performed, together with microbiological examinations of any biological materials taken when symptoms of infection were observed.

\section{Results}

Altogether $28.9 \%$ of the residents had wheelchair disability or were bedridden, $10.6 \%$ - disoriented in time and/or space, $49,5 \%$ had urinary incontinence and 35,3\% fecal incontinence. Prevalence of MDRO was found to be $12.4 \%$. The most common pathogens were MRSA, which consisted $43,2 \%$ of all $S$. aureus isolates $(\mathrm{n}=94)$ and $\operatorname{ESBL}(+)$ rods, which reached $13,9 \%$ out of 165 Enterobacteriaceae isolates. Factors independently (all $\mathrm{p}<0.05)$ associated with MDRO were asymptomatic bacteriuria, urinary and/or fecal incontinence, wheelchair disability or bedridden, low value of the Barthel and Katz Indexes and others.

\section{Conclusion}

This study showed that the prevalence of MRSA and $\operatorname{ESBL}(+)$ rods was lower then in other similar studies

Jagiellonian University Medical School, Kraków, Poland published recently. Unfortunately, microbiology tests were done not in all cases of infections which occurred during the study like as sputum samples from suspected pneumonia $(14,3 \%)$. Thus, results obtained by us, importance of infection control for elderly patients. * This study was supported by the grant from the Ministry of Science and Higher Education (N N404 047236).

\section{Disclosure of interest}

None declared.

Published: 29 June 2011

doi:10.1186/1753-6561-5-S6-P160

Cite this article as: Wojkowska-Mach et al:: Selected mutli-drug-

resistance-organisms in selected Polish long-term-care facilities*. BMC Proceedings 2011 5(Suppl 6):P160.
Submit your next manuscript to BioMed Central and take full advantage of:

- Convenient online submission

- Thorough peer review

- No space constraints or color figure charges

- Immediate publication on acceptance

- Inclusion in PubMed, CAS, Scopus and Google Scholar

- Research which is freely available for redistribution
C Biomed Central

\section{Biomed Central}

